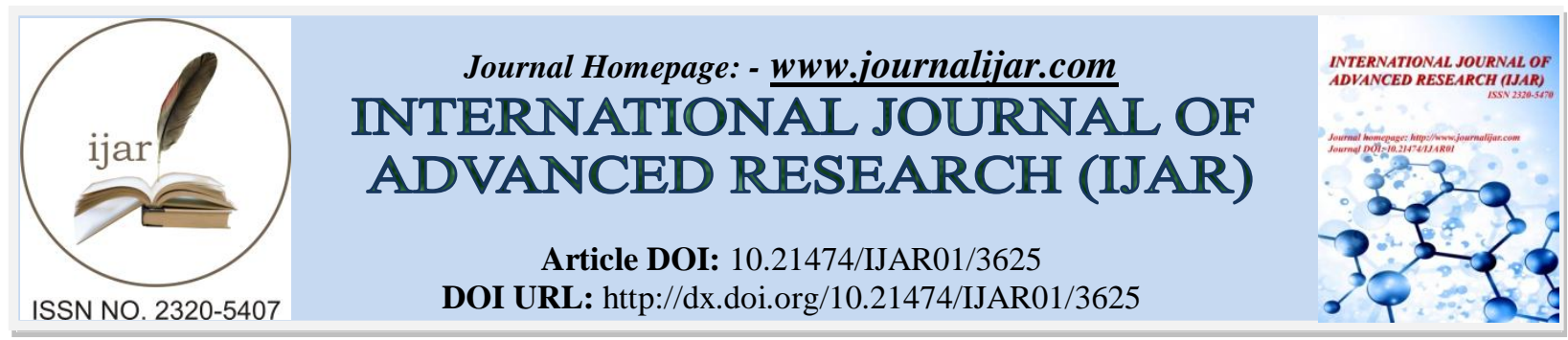

RESEARCH ARTICLE

\title{
TO ENHANCE THE PERFORMANCE OF SOLAR STILL WITH REFLECTORS
}

\begin{abstract}
Mohd Zaheen Khan and I. Nawaz.
Department of Mechanical Engineering, Faculty of Engineering \& Technology, Jamia Millia Islamia, New Delhi110025, India.
\end{abstract}

\section{Manuscript Info}

Manuscript History

Received: 07 January 2017

Final Accepted: 08 February 2017

Published: March 2017

Key words:-

Solar Still, Reflector, Productivity, Solar Distillation

\begin{abstract}
The solar still is an errorless well spring of freshwater for farming and drinking in far away, widely different areas or islands. There are great numbers of sort of solar stills the least difficult and most put examples on view of is the basin solar still. Observations put examples on view of that the common still has limited amount produced. Researches have taken determinations to make different designs of solar stills to get well the amount produced and got knowledge by reasoning that solar stills incorporated with reflectors are the most efficient and effective Designs The reflectors, either outside or inside, are a good and cheap modification to increase the solar irradiation given direction to the basin liner or the water along with the distillate efficiency of the still. In this paper, a wide measures taking for different solar stills with reflectors has been showed.
\end{abstract}

Copy Right, IJAR, 2017,. All rights reserved.

\section{Introduction:-}

People existing in isolated areas or islands, where freshwater source by transport is costly, face the problem of water scarcity every day. Solar still offerings specific advantages to be used in these ranges due to its easier production, minimum skills of operation and preservation requirements, and responsiveness to the environment. The clean free and ecofriendly to the environment are two major benefits which strengthen the use of solar stills. The main drawback of solar stills is the low production of freshwater in comparison with the other distillation systems. The production volume for a simple type solar still is only between $2-5 / \mathrm{m}^{2} /$ day. This makes the solar stills uneconomic compared to the other conventional distillation systems [1].Many researchers have reviewed, comprehensively, the latest work on solar stills such as classification [2],design[3], improvement techniques [4], passive[5], active [6], inclined [7], stepped[8], wick type[9], and condensers with solar stills [10]. There is no specific manageable survey on solar stills with reflectors. Along these lines, this work is to make a documental study on the solar stills combined with external reflectors and internal reflectors.

\section{Conventional Solar Still with Reflectors:-}

Internal reflectors are suitable tools to concentrate and transmit solar radiation. They are suggested when sunlight is weak or the local temperature is comparatively low. External reflectors are ideal to be used to change the direction of solar rays to improve the flexibility of the absorber plate configuration such as vertical solar absorber plate which helps to recover the vapor latent heat of condensation. External and internal reflectors are suggested when sunlight is weak or the local temperature is discreetly low shown in Figure no 1.

Corresponding Author:- Mohd Zaheen Khan

Address:- Department of Mechanical Engineering, Faculty of Engineering \& Technology, Jamia Millia Islamia, New Delhi- 110025, India. 


\section{Categorization of reflector with solar stills:-}

To get high distillation production, scientists introduced many efforts to make different design of solar stills. They concluded the solar still integrate with reflectors is effective and efficient. The reflectors with solar stills can be distributed into three types (1) internal reflectors (2) external reflectors both top and bottom, and combination of internal and external reflectors. To utilize the external and internal reflectors can bean economical method to expand the solar irradiation incident on the basin liner to make high productivity as possible. A simple valuation of different solar stills with reflectors is showed in Table no 1. The evaluation based on location, daily productivity, yield improvement and efficiency.

\section{Internal reflectors (IR):-}

The reflectors inside the solar still affect significantly the output of distilled water, which is credited to the centralization of the reflected solar radiation incident on the water. Besides, reflectors decrease the waste heat energy from solar still. Tamimi [11] studied experimentally the performance of a single slope solar still

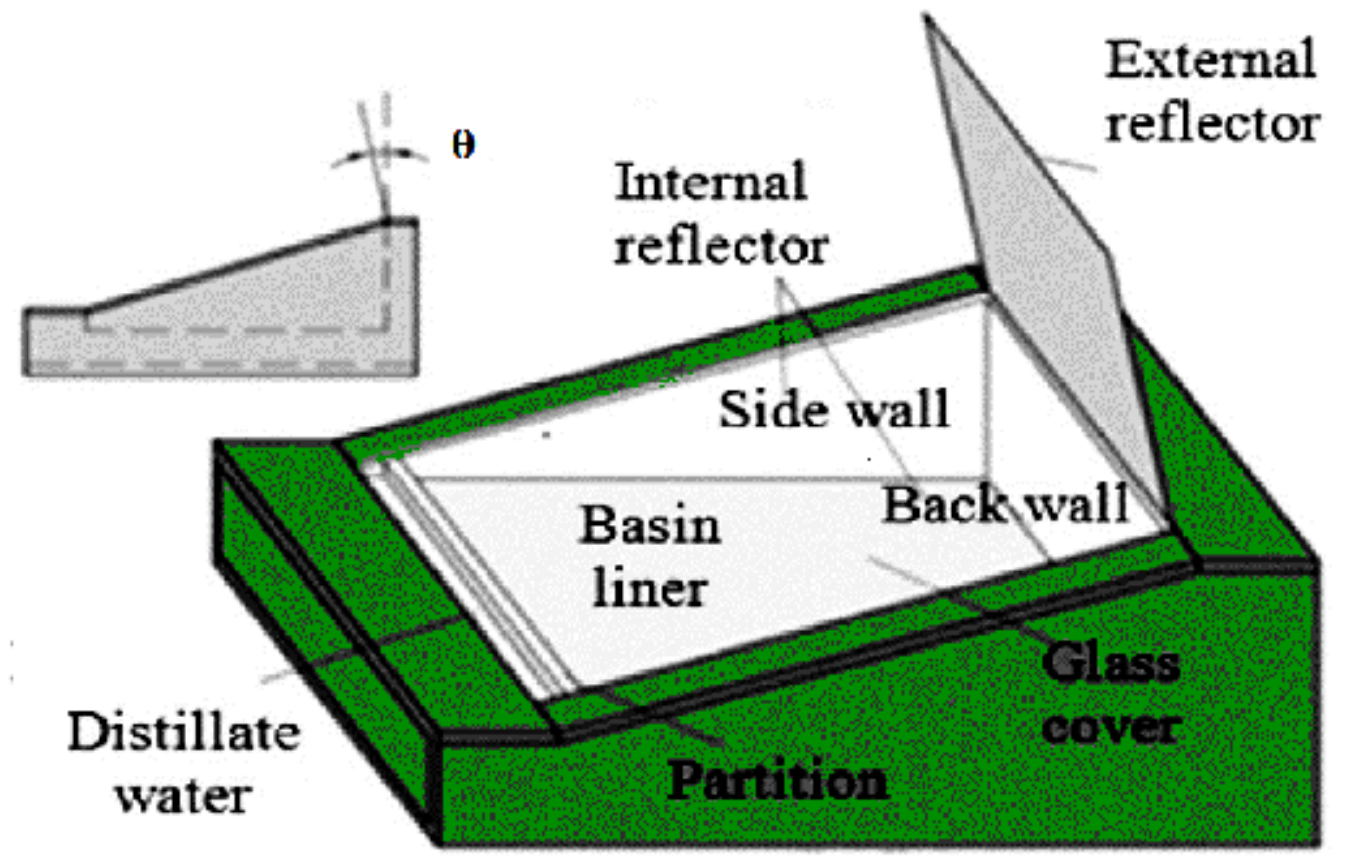

Figure 1:- A Solar Still basin with reflector

Single basin solar still with mirrors installed on the side walls of a still. They concluded that by using mirrors the basin efficiency increases during the whole day. El Swify and Metias [12] used scientific modeling and conducted experiments to find out the effect of internal reflectors on the back and side walls of a single slope solar still with its back wall acting as an additional condenser showed in Figure No.2. They mentioned that the distillation increase of $80 \% \& 20 \%$ can be obtained from installing reflectors in the summer and winter season, respectively. New designs of solar still consist of a metallic cylindrical parabolic reflector studied by Minasian et al. [13]. The reflector was design to concentrate incident solar radiation on the black outside surface of a tray located on the focal line of the reflector. The tray was lined with blackened wick, which represents the evaporative surface of proposed still which was shown in Figure no. 3. They showed that the productivity of the latest still was $23-33 \%$ greater than that of a conventional basin type solar still .Abdallah et al. [14] provides the modified basin solar still. The design modification was fix the interior reflecting mirrors on the internal walls of the still to minimize the amount of energy lost shows in Figure no 4.The experimental result was shows that the use of internal mirrors improved the system thermal performance up to $32 \%$. The solar still design was modified from flat basin to stepwise basin and the efficiency increases by a normal value of $185 \%$. AlHayek and Badran [15] compared the performances of a double slope basin solar still and a single slope basin solar still. The inside surfaces of complete walls were made of mirrors. They performed their experiments during July and determined that using mirrors on the inside walls of the single slope basin solar still improved the production of distilled water by $18 \%$ higher than the double basin solar stills. The effect of an internal reflector on the production of a single slope solar still (during the winter and summer) 
was examined experimentally and theoretically by Karimi et al. [16].They presented a scientific model considering the effect of all walls(east, west, north and south) of the solar still on the amount of received solar radiation to brine. The model was validated with the experimental data. The model can calculate the yield of the still with and without Internal Reflector on various walls. The result shows the simultaneous use of Internal Reflector on front and side walls enhances the solar still efficiency by $16 \%$. Though, installation of an Internal Resistance on the back wall can increase the annual efficiency by $20 \%$. The installation of Internal Resistance on all walls in comparison to a still without Internal Reflector can increase the distillate production at winter, summer, and the entire year by $60 \%, 20 \%$, and $31 \%$, respectively. Modification of the stepped solar still over installing Internal Reflector on the vertical side which was introduced by Omara et al. [17].The productivity of the stepped solar still with Internal Reflector was higher than that without the Internal Reflector. The results also indicated that the productivity of the modified stepped solar still with and without Internal Reflector is higher than that of the conventional solar still by almost $70 \%$ and $50 \%$, respectively. Also, the efficiency of the stepped solar still with reflectors and without reflectors was $54 \%$ and $51 \%$ respectively, whereas, the efficiency of the conventional solar still was only $32 \%$.The performance factors of the Corrugated Solar Still (CSS)and Conventional Solar Still (CnSS) were studied experimentally by Omara et al. [18]. The author's view concerns with using both double layer wick material and reflectors composed inside the CSS, Figure no 5.Inaddition, the influence of saline water depth $(1.5,2.5$, and $3.5 \mathrm{~cm})$ on CSS performance was also studied. During investigations, the product of CSS with wick and reflectors is about $146 \%$ higher than the CSS at a brine depth of $1.5 \mathrm{~cm}$. In addition, the daily efficiencies of CSS and CnSS were approximately $60 \%$ and $35 \%$, respectively. In other experimental study by Omara et al. [19], a hybrid solar distillation system covering of corrugated and wick absorbers of solar stills was combined with an external condenser and internal reflectors to study their performance. They showed that the productivity of corrugated wick still with reflectors and external condenser was improved by about $182 \%$ over CnSS at a brine depth of $1.5 \mathrm{~cm}$.

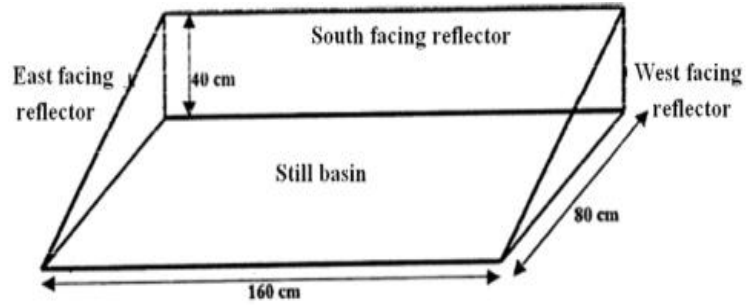

Figure 2:- Double Exposure solar still With Internal Reflectors.

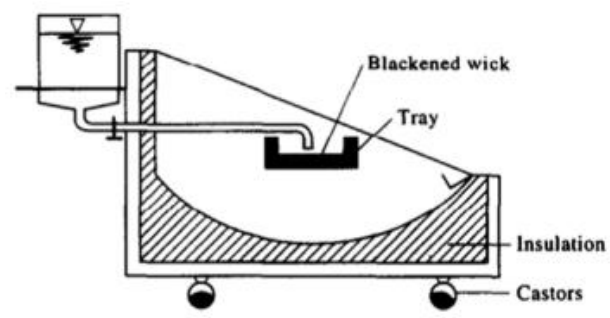

Figure 3:- Basin solar still with cylindrical parabolic reflector.

\section{External reflector (ER):-}

The external reflector used in the solar still are made up of greatly reflective materials such as mirror finished metal plate. The diffuse and direct beams transmitted over the glass cover are improved by using the ER. Scientist (Hiroshi Tanaka) is the most concerning to study the effect of reflector on the distillate of stills.

\section{External top reflectors:-}

Tanaka et al. [20-22] showed numerical investigation on a tilted wick solar still with a top mirror (vertical [20], forwards [21] and backwards [22]) extending from the upper edge of the still. They displayed geometrical models to compute the solar irradiation reflected from a top mirror and then absorbed on the evaporating wick. They concluded that the top mirror can increase the absorbed solar radiation by evaporating wick, and added, the amount of solar irradiation reflected from the top mirror and absorbed on the wick can be enhanced by inclining the top mirror to be backwards in summer and forwards in winter. A theoretical analysis was used by Tanaka and Nakatake [20] to study the effect of a vertical flat plate External Reflector on the productivity of a TWSS and shows the average increase of 
$10 \%$ in a year. Another theoretical analysis of a top External Reflector with TWSS on a winter was investigated by Tanaka and Nakatake [21]. Their results indicated that the productivity of a still with an inclined reflector would be around $12 \%$ or $25 \%$ over that with a vertical reflector when the reflector length is a half of or the same as the solar still length. In adding, a theoretical analysis was made on TWSS with external top reflector with the aim of determining optimum inclination for both reflector and solar still for different seasons by Hiroshi Tanaka [22], Figure No 5. Regarding to the results obtained, $30^{\circ} \mathrm{N}$ latitude was represented as the best inclination angle either for the still or the reflector monthly. In addition, he concluded that for any season the daily productivity of the solar still can be improved by adjusting the inclination of both the reflector and solar still, thus producing around $20 \%$ over the traditional TWSS throughout the year. Tanaka and Nakatake [23] displayed another theoretical investigation of one step azimuth tracking TWSS with a vertical flat plate reflector. The TWSS is assumed to be rotated manually just once a day at southing of the sun. They performed numerical analyses of heat and mass transfer in the still to determine the daily productivity of the still on four typical days: the spring and autumn equinoxes and summer and winter solstice days at $29^{\circ} \mathrm{N}$ latitude. For four days, results indicated that the increase in the productivity of TWSS would be around $40 \%$, and can be accomplished by the simple modification of utilizing a reflector.E1-Bahi and In an [24] examined a conventional still integrated with an outside condenser in Figure No 6.

Table 1:- Simple comparison of different solar still with reflectors

\begin{tabular}{|c|c|c|c|c|c|c|c|}
\hline No & Categorization & Authors & $\begin{array}{l}\text { Locations } \\
\text { (Latitude) }\end{array}$ & $\begin{array}{l}\text { Reflector } \\
\text { material }\end{array}$ & $\begin{array}{l}\text { - Daily yield }\left(\mathrm{kg} / \mathrm{m}^{2} / \mathrm{d}\right) \\
\text { - Improvement } \\
\text { - Efficiency }\end{array}$ & $\begin{array}{l}\text { Reflectors effect } \\
\text { (\%) }\end{array}$ & Observations in experiment \\
\hline \multicolumn{8}{|c|}{ 1. Internal reflectors } \\
\hline 1 & & $\begin{array}{l}\text { El-Swify et al. } \\
{[12]}\end{array}$ & $\begin{array}{l}\text { Cairo, Egypt }\left(25^{\circ}\right. \\
\text { N) }\end{array}$ & Mirrors & $\begin{array}{l}3.05-7.2 \\
82.6 \% \text { in winter } 22 \% \\
\text { in summer } \\
-\end{array}$ & $\begin{array}{l}82.6 \% \\
22 \%\end{array}$ & $\begin{array}{l}\text { The cooling effect of the back glass } \\
\text { cover, back condenser, is improved due } \\
\text { to the higher temperature difference as } \\
\text { compared to the ordinary one. }\end{array}$ \\
\hline 2 & Conventional still & $\begin{array}{l}\text { Minasian et al. } \\
\text { [13]. }\end{array}$ & $\begin{array}{l}\text { Baghdad, Lraq, } \\
\left(33.33^{\circ} \mathrm{N}\right)\end{array}$ & $\begin{array}{l}\text { Stainless } \\
\text { steel }\end{array}$ & $\begin{array}{l}1.23-6 \\
25-35 \% \\
-\end{array}$ & $25-35 \%$ & $\begin{array}{l}\text { The productivity of the conventional } \\
\text { basin type solar still has been increased } \\
\text { by using a stainless steel cylindrical } \\
\text { parabolic reflector. }\end{array}$ \\
\hline 3 & & $\begin{array}{l}\text { Abdallah et al. } \\
\text { [14] }\end{array}$ & $\begin{array}{l}\text { Amman, Jordan, } \\
\left(32^{\circ} \mathrm{N}\right)\end{array}$ & Mirrors & $\begin{array}{l}1.64 \\
30 \% \\
\sim\end{array}$ & $30 \%$ & $\begin{array}{l}\text { Installing internal side mirrors gave } \\
\text { better performance because these } \\
\text { mirrors make use of the energy } \\
\text { reflected on all sides of the solar still. }\end{array}$ \\
\hline 4 & & $\begin{array}{l}\text { AlHayek and } \\
\text { Badran [15] }\end{array}$ & $\begin{array}{l}\text { Amman, Jordan } \\
\left(32^{\circ} \mathrm{N}\right)\end{array}$ & Mirrors & $\begin{array}{l}- \\
20 \% \\
11 \%\end{array}$ & $20 \%$ & $\begin{array}{l}\text { Performance characteristics of the stills } \\
\text { showed that the temperature at the } \\
\text { water surface is increased with } \\
\text { decreasing water depth, and by the } \\
\text { addition of dye. }\end{array}$ \\
\hline 5 & & $\begin{array}{l}\text { Karimi et al. } \\
{[16]}\end{array}$ & Iran. $\left(30^{\circ} \mathrm{N}\right)$ & Mirrors & $\begin{array}{l}- \\
34 \% \\
-\end{array}$ & $34 \%$ & $\begin{array}{l}\text { The installation of IRs on all walls in } \\
\text { comparison to a still without IR can } \\
\text { increase the distillate production at } \\
\text { winter, summer and the entire year by } \\
65 \%, 22 \% \text { and } 34 \% \text {, respectively. }\end{array}$ \\
\hline 6 & Stepped solar still & $\begin{array}{l}\text { Omara et al. } \\
{[17]}\end{array}$ & $\begin{array}{l}\text { Kafrelsheikh, } \\
\text { Egypt, }\left(31.07^{\circ} \mathrm{N}\right)\end{array}$ & Mirrors & $\begin{array}{l}6.35 \\
75 \% \\
56 \%\end{array}$ & $18 \%$ & $\begin{array}{l}\text { Productivity of stepped still with and } \\
\text { without internal reflectors was higher } \\
\text { than the conventional still by } 75 \% \text { and } \\
57 \% \text { respectively. }\end{array}$ \\
\hline 7 & Corrugated wick solar still & $\begin{array}{l}\text { Omara et al. } \\
\text { [18] and [19] }\end{array}$ & $\begin{array}{l}\text { Kafrelsheikh, } \\
\text { Egypt, }\left(31.07^{\circ} \mathrm{N}\right)\end{array}$ & Mirrors & $\begin{array}{l}4.1 \\
145.5 \% \\
58 \%\end{array}$ & $55 \%$ & $\begin{array}{l}\text { The yield of Corrugated wick solar still } \\
\text { with reflectors when providing a } \\
\text { vacuum was enhanced to about } 180 \% \\
\text { higher than the conventional still. }\end{array}$ \\
\hline
\end{tabular}




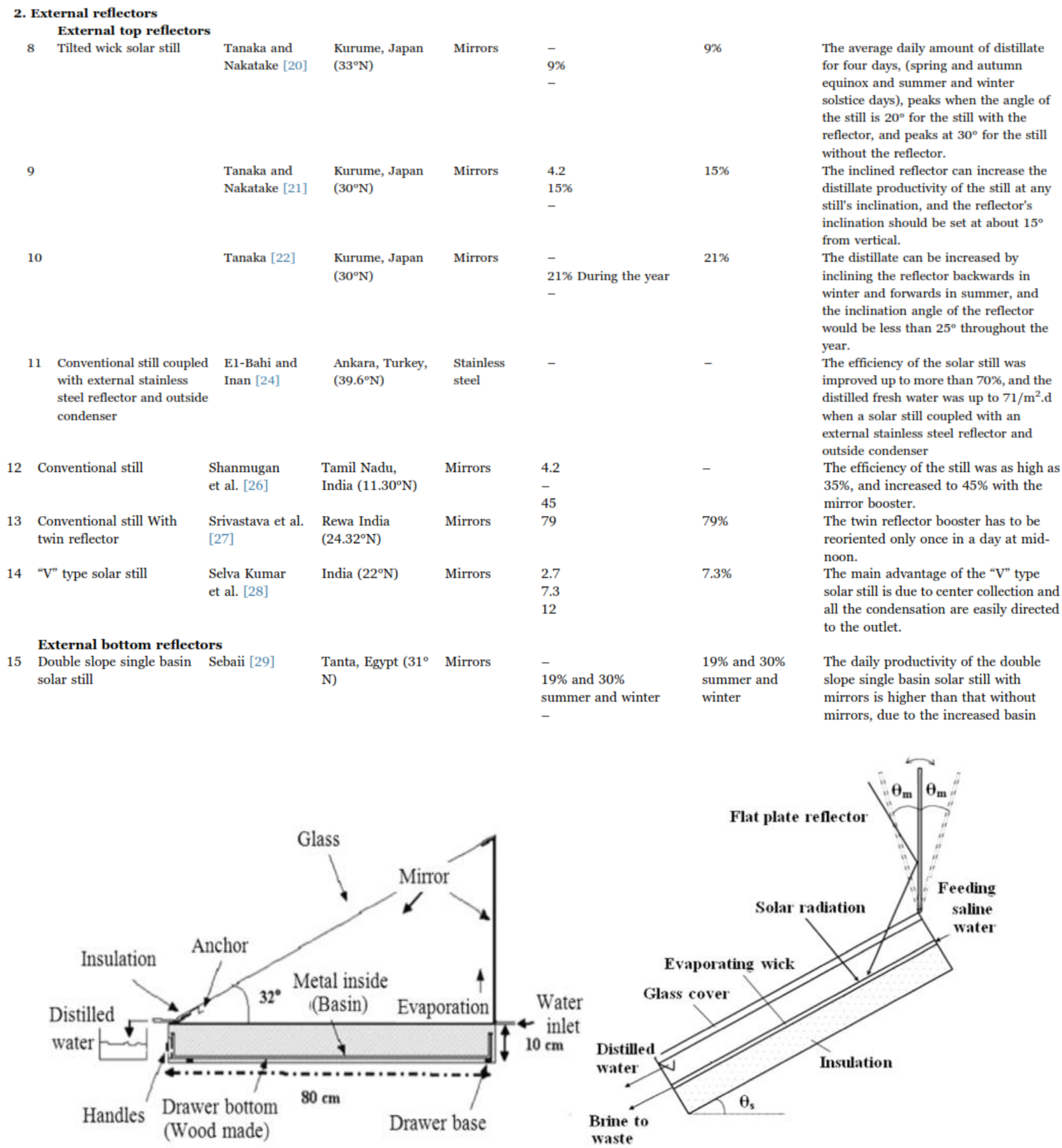

Figure 4: basin solar still with Internal Reflector
Figure 5: Top reflector with TWSS 


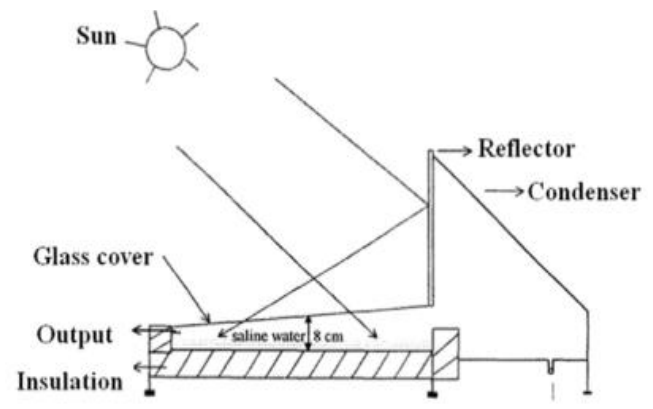

Figure 6:- Conventional Still integrated with top reflector.

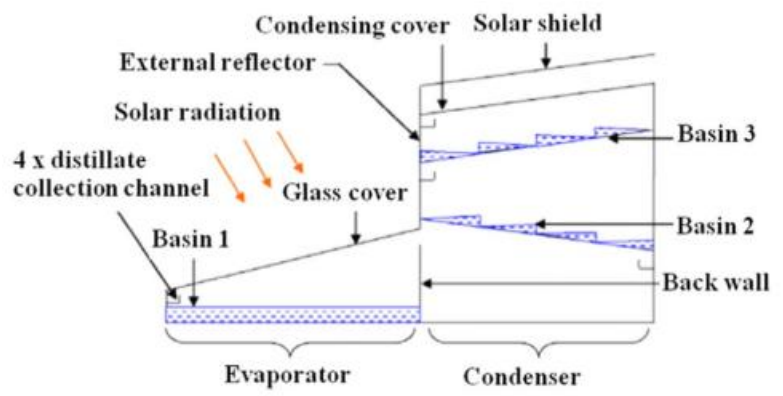

Figure 7:- Basin solar still with reflector and external condenser.

A reflector made of stainless steel was added to the glass cover to reflect the solar radiation into the still basin through the glass cover and to give a shadow for the condenser. The study led to the conclusion that the efficiency of the solar still was enhanced by about $72 \%$ and the daily productivity was up to $71 / \mathrm{m}^{2}$ a day. Madhlopa and Johnstone [25] proposed a model to calculate the distribution of solar irradiation inside a conventional still with reflector and external condenser, Figure no 7. The system had one basin in the evaporation chamber and two other basins in the condenser chamber. It had a glass cover over the evaporator basin and an opaque condensing cover over basin 3. Water vapor from the first basin condenses under the glass cover while the remainder flows into the condenser by purging, diffusion, and condenses under the liner of basin 2. They found that distilled freshwater was about $2.1 \mathrm{~kg} / \mathrm{m}$ a day. The performance of an acrylic mirror boosted solar distillation unit was studied by Shanmugan et al. [26]. The performance of solar still in terms of distilled water collection has been analyzed and a booster mirror (acrylic) was attached just above the glass cover of solar still. The mirror boosting reflects the excess solar radiation to water and it is possible to adjust the booster mirror for perfect reflection depending upon the sun moving angle. The maximum amount of water collected per day was about $4.1 \mathrm{~L}$. The efficiency of the still was as high as $33 \%$, and increased to $43 \%$ with the mirror booster. Srivastava et al. [27] performed experiments of a modified solar still with multiple low thermal inertia porous absorbers, Figure no 8 . The absorbers were made up of jute cloth and they float on the basin water with the help of thermocol insulation. The surfaces of the absorbers were always wet and hence there were no dry spots. The results showed that the productivity was $66 \%$ more than the conventional still and $33 \%$ more on cloudy days. The basin water below the floating absorber remained warm during offshine hours, and hence, the distillate was produced even at nights. A twin reflector booster was placed perpendicular to each other on the modified stills. The productivity increased by $77 \%$ over the still without booster. The thermal performance of a "V" type solar still with a charcoal absorber was analyzed by Selva Kumar et al. [28]. The main advantage of this type of still is that the distilled water collection was directed towards the central water collection channel as shown in Figure no 9. The production of the outlet distillate water had increased. The overall efficiency was found to be $25 \%$ and $12 \%$ for the still without and with the boosting mirror, respectively. He also conducted similar experiments which were carried out for the charcoal absorber in the still without and with the boosting mirror which yielded $30 \%$ and $14 \%$ respectively. 


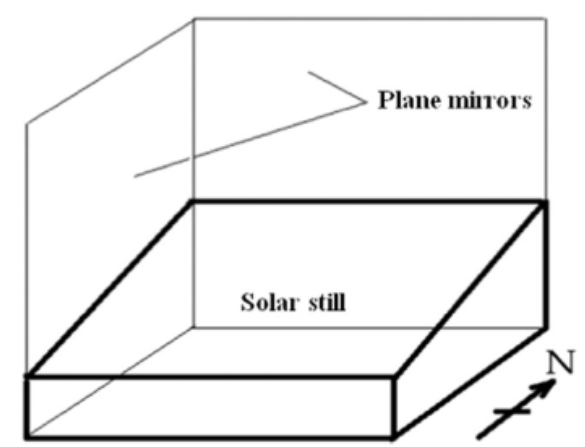

Figure 8:- Twin reflector booster applied to solar still.

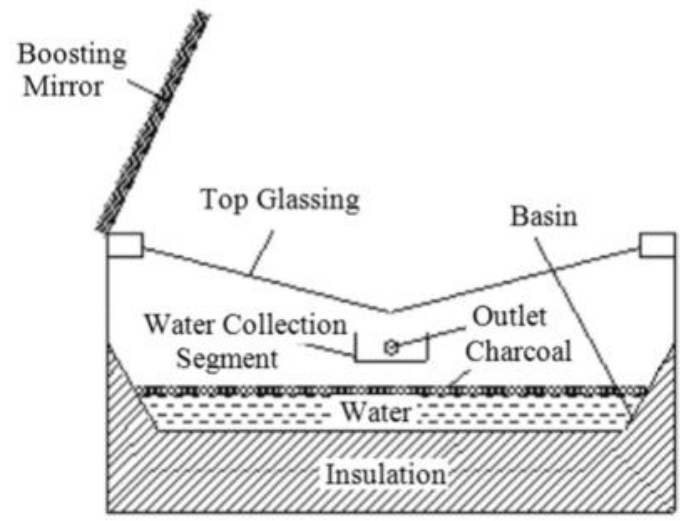

Figure 9:- V type solar still with External reflector.

\section{Scope for further research:-}

There are still some problems and challenges on the design of solar stills not being clearly analyzed for performance improvement, including solar stills with reflectors. This paper reviews the studies and developments of solar stills with reflectors. The results from the preceding work done clearly show that the enhancement of solar stills with reflectors performance differs greatly for different techniques due to different experimental conditions. The review represents specific inferences drawn from the analyses of solar stills with reflectors by various authors to pave way researchers to grasp the previous designs and to fabricate new designs with optimum design parameters for higher distillate output.

The following factors may be taken into consideration for further research of solar stills with reflectors:

\section{For active solar still:}

1.1 Combine solar still with solar water heater in order to increase the basin temperature.

1.2 For active solar stills, more research may be carried out with reflectors.

1.3 Further studies should be conducted to improve the solar stills productivity, especially in the fields of coupling with heat storage and various waste heat sources.

\section{For tracking system:}

1.4 Solar still with azimuth sun tracking and just an adjustment of the optimum elevation of the day.

1.5 Combine the solar still with sun tracking and the solar water heater.

1.6 The sun tracking system is more effective than fixed still and it is capable of improving the distillate output of the still with reflectors.

\section{Conclusions:-}

Reflectors are used to enhance the daily amount of distillate of the solar still. The accompanying conclusions can be inferred on the basis of above discussions

$>$ Installing reflectors is more practical in places where solar radiation is weak and the ambient temperature is relatively low. 
$>$ Installation angle of the external reflector should be changed with the seasons to enhance the productivity through all the year.

$>$ The external reflector is inclined backwards or forwards according to the month.

$>$ The daily productivity can be increased by adjusting the inclination of both the still and reflector mirror in any season.

$>$ The benefits of both the inclined external top and internal reflectors would be considerably less in summer than in winter.

Dor the still with larger angle of the glass cover, the effect of the external top reflector would be smaller.

$>$ The vertical flat plate external reflector would be less effective for the tilted wick solar still than for the conventional still.

\section{References:-}

1. Velmurugana V, Srithar K. Performance analysis of solar stills based on various factors affecting the productivity-a review. Renew Sustain Energy Rev2011;15: 1294-304.

2. Aayush Varun K. Solar stills: a review. Renew Sustain Energy Rev 2010;14:446-53.

3. Vishwanath PK, Kr Anil, Om P, Ajay KKi. Solar stills system design: a review. Renew Sustain Energy Rev 2015;51:153-81.

4. Sivakumar V, Ganapathy Sundaram E. Improvement techniques of solar still efficiency: a review. Renew Sustain Energy Rev 2013;28:246-64.

5. Durkaieswaran P, Kalidasa KM. Various special designs of single basin passive solar still-A review. Renew Sustain Energy Rev 2015;49:1048-60.

6. Sampath kumar K, Arjunan TV, Pitchandi P, Senthil kumar P. Active solar distillation-a detailed review. Renew Sustain Energy Rev 2010;14:1503-26.

7. Ajay KK, Akhilesh Y, Amit S. Inclined solar still designs: a review. Renew Sustain Energy Rev 2016;54:42951.

8. Kabeel AE, Omara ZM, Younes MM. Techniques used to improve the performance of the stepped solar stillA review. Renew Sustain Energy Rev 2015;46:178-88.

9. Manikandan V, Shanmugasundaram K, Shanmugan S, Janarthanan B,Chandrasekaran J. Wick type solar stills: a review. Renew Sustain Energy Rev2013;20:322-35.

10. Kabeel AE, Omara ZM, Essa FA, Abdullah AS. Solar still with condenser-A detailed review. Renew Sustain Energy Rev 2016;59:839-57.

11. Tamimi A. Performance of a solar still with reflectors and black dye. Sol Wind Technol 1987;4:443-6.

12. El-Swify ME, Metias MZ. Performance of double exposure solar still. Renew Energy2002;26:531-47.

13. Minasian AN, Al-Karaghouli AA, Habeeb SK. Utilization of a cylindrical parabolic reflector for desalination of saline water. Energy Convers Manag 1997;38:701.

14. Abdallah S, Badran O, Abu-Khader MM. Performance evaluation of a modified649design of a single slope solar still. Desalination 2008;219:222-30.

15. Al-HayekI, Badran OO. The effect of using different designs of solar stills on water distillation. Desalination 2004;169:121-7.

16. Karimi Estahbanati MR, Ahsan Amimul, Feilizadeh Mehrzad, Jafarpur Khosrow,Ashrafmansouri SeyedehSaba, Feilizadeh Mansoor. Theoretical and experimental investigation on internal reflectors in a single-slope solar still. Appl Energy2016;165:537-47.

17. Omara ZM, Kabeel AE, Younes MM. Enhancing the stepped solar still performance using internal reflectors. Desalination 2013;314:67-72.

18. Omara ZM, Kabeel AE, Abdullah AS, Essa FA. Experimental investigation of corrugated absorber solar still with wick and reflectors. Desalination2016;381:111-6.

19. Omara ZM, Kabeel AE, Essa FA. Effect of using nanofluids and providing vacuumon the yield of corrugated wick solar still. Energy Convers Manag2015;103:965-72.

20. Tanaka H, Nakatake Y. Improvement of the tilted wick solar still by using a flatplate reflector. Desalination 2007;216:139-46.

21. Tanaka H, Nakatake Y. Increase in distillate productivity by inclining the flat plateexternal reflector of a tiltedwick solar still in winter. Sol Energy 2009;83:785-9.

22. Tanaka H. Tilted wick solar still with external flat plate reflector: optimum inclination of still and reflector. Desalination 2009;249:411-5.

23. Tanaka H, Nakatake Y. One step azimuth tracking tilted-wick solar still with a vertical flat plate reflector. Desalination 2009;235:1-8. 
24. E1-Bahi A, Inan D. A solar still with minimum inclination, coupled to an outside condenser. Desalination 1999;123:79-83.

25. Madhlopa A, Johnstone C. Computation of solar radiation distribution in a solar still with internal and external reflectors. Sol Energy 2011;85:217-33.

26. ShanmuganS, Rajamohan P, Mutharasu D. Performance study on an acrylic mirror boosted solar distillation unit utilizing seawater. Desalination 2008;230:281-7.

27. Pankaj SK, Agrawal SK. Experimental and theoretical analysis of single sloped basin type solar still consisting of multiple low thermal inertia floating porous absorbers. Desalination 2013;311:198-205.

28. Selva Kumar B, Kumar Sanjay, Jayaprakash R. Performance analysis of a V type solar still using a charcoal absorber and a boosting mirror. Desalination2008;229:217-30.

29. Sebaii AA. Effect of wind speed on some designs of solar stills. Energy Convers Manag 2000;41(6):523-38.

30. Tanaka H, Nakatake Y. Factors influencing the productivity of a multiple effect diffusion-type solar still coupled with a flat plate reflector. Desalination2005;186:299-310. 